\title{
FASHION INDUSTRY IN BRAZIL: PRODUCTIVE AND SPATIAL PROFILE AND THE EMERGENCE OF FASHION LAW
}

\author{
*Sérgio Duarte de Castro and Sidelcy Ludovico Alves Martins
}

Pontifícia Universidade Católica de Goiás (PUC-GO)

\section{ARTICLE INFO}

\section{Article History:}

Received $20^{\text {th }}$ March, 2021

Received in revised form

$06^{\text {th }}$ April, 2021

Accepted $08^{\text {th }}$ May, 2021

Published online $30^{\text {th }}$ June, 2021

\section{Key Words:}

Fashion Industry; Fashion Law;

Fashion, Legal Security, Autonomy.

\section{*Corresponding author:}

Sérgio Duarte de Castro

\begin{abstract}
This article addresses the Brazilian fashion industry's productive and spatial profile. The study demonstrates its importance and the need to move forward in constructing a new legal discipline with its own body of rules that regiment the complex relationships involving the creative process and its trade products. Therefore, we outline the Brazilian fashion industry profile and show the advances in several countries to define this new law's boundaries. Compared with the Brazilian case, we have concluded that despite the progress, the country is falling behind and in need of more firm actions to guarantee the legal security crucial to this industry's continued development.
\end{abstract}

Copyright (C) 2021, Sérgio Duarte de Castro and Sidelcy Ludovico Alves Martins. This is an open access article distributed under the Creative Commons Attribution License, which permits unrestricted use, distribution, and reproduction in any medium, provided the original work is properly cited.

Citation: Sérgio Duarte de Castro and Sidelcy Ludovico Alves Martins. 2021. "Fashion industry in Brazil: Productive and spatial profile and the emergence of fashion law", International Journal of Development Research, 11, (06), 48027-48032.

\section{INTRODUCTION}

This article addresses the Brazilian fashion industry's productive and spatial profile. It presents a study on the importance of the consolidation of fashion law as an autonomous discipline in our country. Fashion law's primary purpose is to provide legalsecurity and foster national and international peacemaking relations among the manifold participants in this significant Brazilian economic segment's productive system. Apart from the introduction, this article has another three sections: discussion, final considerations, and references. In the discussion section, first, we analyze some issues related to the world of fashion and its industry. Therefore, we discuss how to construct a new legal discipline's autonomy and its constituting aspects, the fashion's concept, the fashion industry's concept, and the Brazilian fashion industry's characteristics. Besides, we give an overview of fashion law's origin worldwide and its history. Finally, we consider the challenges faced by fashion law in the Brazilian context. In the last section, we present a brief conclusion of the whole discussion, pointing out the need and ways to reach an immediate solution to this problem.

\section{DISCUSSION}

The emergence of a new legal discipline: First of all, to address fashion law's autonomy, we need to analyze the social and economicreality surrounding the world of fashion. Only then can we establish the content that will make its long-waited autonomy possible (ALMEIDA, 2019). For most authors, recognizing the autonomy of a new legal discipline means meeting some requirements. According to the Italian Alfredo Rocco, for instance, there are three criteria to establish the autonomy of a legal branch: a) the existence of a specific thematic field; b) own theories, and c) specific methodology (OLIVEIRA, 2004).

Legal disciplines and their constitutive parts: On the other hand, for the doctrine, legal knowledge can be built in diverse ways; through concepts, compartments, classifications, divisions, and groups/clusters. It argues that in the organization of legal knowledge, a division between 'branches' ou 'legal disciplines' plays a relevant role in the outlining of different segments of the legal discourse. By assigning the most suitable position of each object within each compartment, the disciplines will work as principles of interdiction or exclusion, repealing that which does not belong to the segment in question or to the legal universe itself. In this context, each discipline's boundaries encompass the right and the wrong but leave out all that is absurd or unrelated (NETO, 2016).

The concept of fashion: In order to establish the fashion law's thematic field, we have to search for its concept. According to some specialists, the word "moda" (fashion in Portuguese) comes from the Latin "modus," meaning "a way," "a manner," "a custom," and behavior." It can be a trend, a way of dressing, a manner, a custom, a desire. Therefore, the concept of fashion becomes multidisciplinary, for it involves several areas of knowledge such as psychology, 
sociology, anthropology, semiotics of communication, to mention a few. (MIRANDA, 2008, p. 17-18).

That is why not even those who make a living of fashion can conceptualize it, since

(...) fashion is such a diversified business. It is constantly changing, and it is highly ludicrous. Fake eyelashes and push-up bras on one day. Latex clothes and wigs on the other. G-strings bikinis and a uniform the next day. It is like experimenting with my own identity: Who am I going to be today? My free spirit was attracted to fashion (BUNDCHEN, 2018, p. 80).

Accordingly, several authors agree that we must consider psychological factors for the conceptualization of fashion, such as social conformity, search for variety, personal creativity, and sexual attraction. We should also contemplate sociological factors such as forms of collective behavior or social conformity wave (MIRANDA, 2008).

Thus, establishing a precise concept of fashion proves to be a complex task, and some theories have been elaborated for that purpose. They are the theory of fashion as a process, the theory of fashion as a dictatorial process, the theory of fashion as a democratic process, and the theory of fashion as an affirmation process (MIRANDA, 2008). In this sense, fashion is much more than a simple change of attire, wearing a piece of jewelry, or adopting a specific hairstyle or make-up. It involves above all the lifestyle adopted by each individual that, when investing in his/her physical appearance, can cross several territorialities dodging certain prejudices, transforming the body cult into a tactic of social preservation (FERREIRA \& CAMINHA, 2016).

Characterization of the Brasilian fashion industry: Likewise, in order to establish the thematic field of Fashion Law, we need to search for the characteristics of the fashion industry.Its importance to the world economy nowadays is inconsistent; once, according to the 2018 Brazilian Association of Textile Industry (AssociaçãoBrasileira da IndústriaTêxtil /ABIT) data, the fashion industry handled US\$ 35 trillion worldwide (ABIT, 2018).

Table 1. Activities by CNAE 95, which make up the "Fashion Industry"

\begin{tabular}{ll}
\hline Code & Activities \\
\hline Industrial activities \\
\hline 17 & Manufacturing of textile products \\
\hline 18 & Clothing and accessory manufacturing \\
\hline 19 & $\begin{array}{l}\text { Preparation of leather and manufacturing of leather goods, travelling } \\
\text { apparel and footwear }\end{array}$ \\
\hline 24,732 & Manufacturing ofperfumery and cosmetic products \\
\hline 29,645 & $\begin{array}{l}\text { Manufacturing machinery and equipment for the clothing, leather, } \\
\text { and foot wear industries }\end{array}$ \\
\hline 36,919 & $\begin{array}{l}\text { Lapidation of precious and semi-precious stones, goldsmithand } \\
\text { jewelrygoods manufacturing }\end{array}$ \\
\hline Commercial and service activities \\
\hline 51,160 & $\begin{array}{l}\text { Sales representatives and textiles, clothing, footwear, and } \\
\text { leathergoods dealers }\end{array}$ \\
\hline 51,411 & Whole sale of yarn, textiles, fabrics, fabricartifacts and haberdashery \\
\hline 51,420 & Wholesale of clothing goods and accessories \\
\hline 51,438 & Footwear whole sale \\
\hline 51,462 & Wholesale of cosmetics and perfumery goods \\
\hline 52,310 & Retailing of textiles and haberdashery \\
\hline 52,329 & Retailing of clothing godos and accessories \\
\hline 52,337 & Retailing of footwear, leather goods and travel apparel \\
\hline 52,728 & Shoerepair \\
\hline Source: & RAIS. Adapted by the authors.
\end{tabular}

The Brazilian fashion industry involves one of the latest comprehensive productive chains in the occident; it started with the cotton plantations and reached the catwalks of significant fashion show events such as the São Paulo Fashion Week. It corresponds to $2.4 \%$ of the world's textile industry and $2.6 \%$ of the world's clothing industry. These statistics position Brazil as the only major South American country in the textile industry. Still, according to general data of the sector, in 2018, the textile and clothing chain turnover amounted to US $\$ 48.3$ billion, and the average textile production reached the 1.2 million ton mark (FAVARETTO, 2020). Besides, Brazil ranks second in production and third in the consumption of denim (jeans). It owns the fourth largest clothing productive park globally, and it hosts one of the fifth most prominent fashion weeks in the world. Moreover, Brazil is an international reference in beach fashion and homewear design, and it has been standing out in the lingerie and fitness segments (ABIT, 2018). To characterize the fashion industry in Brazil, we used the RAIS (Note 2) database by selecting industrial, commercial, and service activities of the following segments: textile, clothing, leather and footwear, jewelry, perfumery, and cosmetics, which shows in Figure 1.Regardless of the high-leveled sectorial desegregation of this basis, it is impossible to encompass all the activities that integrate this productive system.Therefore, design and fashion shows organization, aside from other fashion-related events, are left out. Nevertheless, the classification achieved results in a highly representative proxy. In commercial and service activities, there is a higher interpenetration between the segments. So, considering the industrial activities only, the most substantial sector is the clothing industry, representing 44.6 $\%$ of the jobs, followed by leather and footwear with $27.3 \%$, and textile with $23.1 \%$ of the employment. The other sectors altogether sum up $5.1 \%$ of formal jobs in he Fashion Industry (Graph 1)

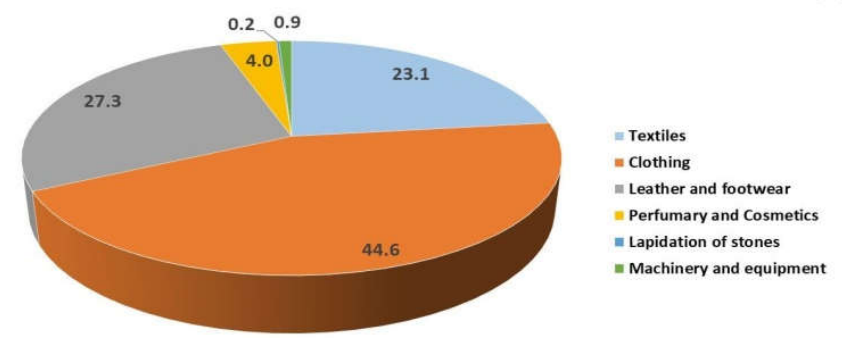

Graph 1. Fashion Industry in Brazil: percentage of jobs in industrial activities by segment (2018)

According to the RAIS 2018 data, the most prominent Brazilian states in the fashion industry are: São Paulo with $25.2 \%$ of the jobs in the segment; Santa Catarina (14.3\%); Rio Grande do Sul (11.5\%); Minas Gerais (10.7\%); Ceará (9.6\%); Paraná (6.6\%), Rio de Janeiro (4.4\%), Bahia (4.2\%), Goiás $(2.7 \%)$ e Pernanbuco (2.3\%). Despite the decrease in the number of formal employments between 2002 and 2018, the segment still creates many jobs in the country. In 2018, it was responsible for $16.8 \%$ of the formal employment in the transformation industry and $12.3 \%$ in commerce. The Brazilian fashion industry employs mostly women, who represent $56.8 \%$ of the jobs in industrial activities and $70.2 \%$ in the commercial segment (RAIS).

Gender issues in Brazilian in Brazilian fashion industry: As usual in the job market, women's salary is inferior to men's in the fashion industry. However, such difference is less significant in the fashion field, both in its industrial and commercial activities, if compared with the transformation industry and commerce in general. The data represented in Graph 2 shows that this difference is minor in commercial activities than in industrial ones.

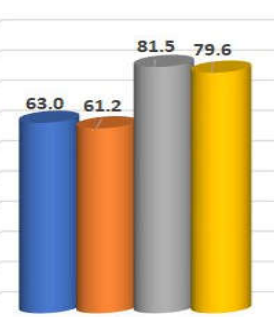

2002

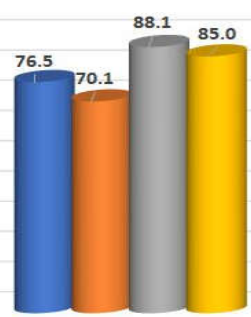

2018
Industry FI Industry Total $=$ Trade FI $=$ TradeTotal

Source: RAIS. Adapted by the authors.

Graph 2. Women's salary as a percentage of men's salary in the Fashion Industry (FI)* and commerce in general in Brazil (2002 and 2018) 
It is also noticeable that the difference between women's and men's salaries decreases over time. Besides, we observe that this trend is more consistent within the fashion industry scope. There was a $23.4 \%$ decrease in the industrial activities' pay differences and $8.1 \%$ in commercial activities between 2002 and 2018. Meanwhile, in the Brazilian transformation industry and commerce in general, within the same period, the reduction in the pay differences between men and women was $14.7 \%$ and $6.8 \%$, respectively (GRAPH 2 ).

\section{Fashion Law}

Fashion Law origin in the global context: Throughout history, we have had unwritten codes on clothing and accessories. In great ancient empires, eastern and western, costumes and adornments were used as forms of social affirmation and differentiation, with implicit rules defining what was appropriate or not for each social group or class and differentiating key power players like kings and emperors.

The first known written rules in this field are the Sumptuary Laws issued in Medieval Europe between the $13^{\text {th }}$ and $17^{\text {th }}$ centuries. These are proclamations of monarchs, parliamentary minutes, local regulations, or even religious decrees that regulated consumption, mainly of food and clothing. Its motivation was to reassure the role of social and political differentiation represented by garments and luxury, in a moment that an emerging business bourgeoisie pursued its place among the dominant classes, flaunting a luxury that was till then a nobility privilege (BOM, 2018). In the $18^{\text {th }}$ century, high fashion emerged in France during the long reign of Louis XIV, which made that country a reference in luxury and sophistication in all aspects. Colbert, Louis' XIV finance minister and one of the key figures of the mercantilist thought, organized a system of guilds and protection for the French market. The normalization from this period was perpetuated in French legislation. Therefore, this is a highly regulated sector to the present day by the French state, with legislation that covers fundamentally high fashion. It defines even the architectural standard that a high fashion studio should have, the minimum number of employees and designers, the number of pieces each collection should have, and other details (GUIMARÃES, 2020). However, only after 2000, has a specific fashion law segment started to be organized in the modern law framework. Among its few researchers, there is no consensus on when it originated.

French origin: To some, the inception of the fashion law term was first used by Canadian attorney Jeanne Belhumeur(Note 3) in 2000 when she published the book Droit International de la Mode, International Fashion Law in English, due to her doctorate thesis Geneva University. That had a significant impact since it was upon this book's publication that the topic started to be studied and organized (OSMAN, 2017). This book addressed questions about the protection of fashion creations in France in the international context and its legal framework. Since then, the author had already realized that fashion transcended national borders, a fact that only now, with e-commerce dictating the rules due to the COVID pandemic, some have perceived (OSMAN, 2017). Despite Jeanne Belhumeur's pioneering spirit, many criticize her work by arguing that it focuses only on high fashion creations that need legal protection for belonging to the art universe. Therefore, the author would leave large-scale creations out and, in turn, all the fashion production system, featured as ample and pulverized among many companies (OSMAN, 2017). Nonetheless, we cannot fail to recognize that only after Jeanne Belhumeur's thesis and her book, countless articles about the subject came up. The issue gained momentum in the international arena.

\section{English origin}

English origin bt Susan Scafidi: Meantime, the most spread theory was that fashion law appeared in the USA. This understanding claims that the creation in 2006 of the fashion law degree in New York by the Fashion Institute of Technology, and, later, Susan Scafidi's initiative to establish a post-grad degree in New York at Fordham University, were the starting point for the subject to gain scientific outlines (OSMAN, 2017).
Susan Scafidi got her law degree at Yale University and, in 2005, kicked off the blog counterfeitchic.com to debate court cases and everyday examples of fashion industry product duplicates. The American Bar Association recognized her website as one of the 100 most influential in American law practice (GIRELLI, 2020; LIRA, 2015).

English origin by Christian Louboutin: However, the most usual doctrine understanding is that fashion law first showed up as a legal subject. That happened when the famous dispute involving designer Christian Louboutin and Yves Saint Laurent brand started in New York court because of the improper use by the brand of the red soles in high-heeled shoes conceived by the designer (IBAIXE JÚNIOR \& SABÓIA, 2014). Before the court litigation, light red shoes had already been created, and Yves Saint Laurent itself released them in 1970. However, they never released them as monochromatic, that is, utterly red on coating and the soles. It turns out that in the spring 2011 season, Yves Saint Laurent relaunched such monochromatic red shoe, which sole, according to Christian Louboutin, resembled much his creation. Opposing to what he considered an improper use, the designer filed a lawsuit in New York court against the Yves Saint Laurent brand for copyright violation. He argued that he had invested a considerable amount in promoting his creation. Such strategy would have fostered his company's growth in the international market, rendering him the red-soled high-heeled shoe designer.

The lawsuit claimed registered trademark violation, unfair competition, false designation of source, and trademark dilution. It petitioned for a preliminary injunction to forbid further trading and market withdrawal of the monochromatic red shoes made by Yves Saint Laurent, aside from asking one million dollars in damages due to client confusion caused by counterfeiting (OSMAN, 2017, 49-50). Furthermore, Christian Louboutin claimed that he had registered his creation as a brand in the appropriate agency, the United States Patent and Trademark Office (USPTO). The trademark was granted in 2008 as a luxury women's footwear design and making him the copyright owner of the Red Sole brand for luxury high heel shoes (MARTINS \& PEREIRA, 2020). The New York court decided that color could not be defined as a brand in the fashion industry environment, implying the agency's trademark was revoked in charge. Not appeased, Christian Louboutin appealed and obtained in higher court a favorable decision confirming that he was the owner of the Red Sole brand and that the trademark should be maintained. However, later Yves Saint Laurent could sell its red shoes as long as they are monochromatic, establishing that the color could be subject to trademark registration if it is an original design (ARROSI \& SOUZA, 2018). In this case, the Court of Appeals understood that, after a detailed analysis on functional brands and aesthetically functional brands, if a product feature is considered functional, it cannot be recognized as a trademark but as a patent. The aesthetically functional brand could be recognized as a trademark as it suggested a specific source of certain consumer products, due to secondary meanings that have their symbology. So, in this case, the red sole shoe became a trademark, making it recognized worldwide as a distinctive element in the consumer mind (OSMAN, 2017). Many times, in the fashion industry, colors were used to identify a brand. For example, Tiffany \& Co owns the trademark for the use of turquoise blue on its packaging materials and Burberry with its checkered pattern applied on many clothing articles (OSMAN, 2017). However, to those advocating that the Christian Louboutin-Yves Saint Laurent litigation resulted in Fashion Law origins, the American legal system used for the first time in this case, mistakenly or not, the theories that debate patents and trademarks in the context of the fashion industry. The advocates of this theory claim that there was discussion about patents and trademarks before, but Louboutin versus Yves Saint Laurent caused repercussion and generated specific questions about the fashion environment, promoting the creation and use of the expression Fashion Law in the USA (IBAIXE JUNIOR \& SABOIA).

Other iniciatives: On the other hand, we cannot fail to mention the initiatives from other experts in this field to debate and improve the 
subject in different legal frameworks as the French and the Portuguese. Let us see then. France, the cradle of high fashion, is home to the three most significant clusters of luxury items producers in the world, Moët Hennessy-Louis Vuitton SE (LVMH), Kering SA, and L'Oreal Luxe. Nevertheless, it still suffers from the consequences of lacking a discipline focused on sector controversies (GAUBERTI, 2020). In the French legal system, fashion law is associated and mixed up with trademark law. Moreover, some authors admit that the subject is expertise which combines many fields of study and tries to understand the challenges of the fashion world in the following years since the industry is going through fast changes and faces many legal threats (KADDOURI, 2018, p. 01). Nonetheless, there are many initiatives to make this possible. One of them was the publication of a supplement in French law magazine Revue Lamy Droit des Affaires in May 2004 by French attorneys, led by Annabelle Gauberti, entitled Droit du luxe. Translated as luxury law or luxury goods law, it highlighted that the addendum exploited many specific legal questions in the fashion industry (OSMAN, 2017, p. 44).

Another initiative was drafting a bill concerning parent companies' supervision duties as a response to the modern slavery act in the UK and the California Transparency in Supply Chains Act, dated March 27, 2017, and integrated into the article L225-102-4 of the French Commercial Code. Besides that, it is publicly known that many companies, such as the French Lactalis, and Crédit Agricole, the Spanish Zara, and the Swedish H\&M, violate repeatedly these legislative provisions (GAUBERTI, 2020). Portuguese Fashion law, one of the most developed in this issue, advanced a lot, thanks to the tireless work of a Portuguese professor from Universidade Católica do Porto, Dr. Ligia Carvalho Abreu. In her view, "fashion law is a legal discipline that focuses on the study of legal relations underlying fashion creation" (ABREU, 2019, p. 12). In partnership with other specialists, Dr. Ligia launched in 2015 a fashion editorial project named Fashion Law - When fashion meets fundamental rights (FLWFMFR) that became a reference in the country concerning fashion law. When it comes to characterizing and distinguishing fashion law as a self-contained and autonomous legal field, these various initiatives try to respond to a specific reality. On the one hand, a reality expressed by the fashion industry's tremendous economic weight as a job and income generator worldwide and, on the other, by the exponential growth of litigations involving this industry. Jimenez (2013), employing a comprehensive survey on the cases in American courts in 2000, showed that the number reached 2,709 litigations, just short of the entertainment industry with 3,299 cases.

The Fashion Law field: The complexity of the fashion industry, a productive and innovative system that embraces various activities and players, raises questions to different legal fields. These questions concern, among others, intellectual property, competition, taxation, environmental issues, work relations, fundamental human rights, animal protection, consumption and consumers, image rights, electronic trade. Therefore, according to Abreu (2019), fashion law has both a public and private legal nature. Many authors in the labor legislation field face the same situation in Brazil, revealing fashion law's multi and interdisciplinarity status. That leads to the study of various branches of legal disciplines. As the author says:

"Therefore, the fashion law's corpus encompasses questions as diverse as the environmental and social impact of raw materials and goods production, labor relations, original creations, new inventions and brand protection, commercial contracts, competition relations, advertisement, the limits of an image as a work of art and the image as a right of the model or person portrayed" (ABREU, 2019, p.12).

Abreu (2019) points out the principles that guide this new legal field: a) sustainable development principle; b) source designation and traceability principle; c) human dignity principle concerning equality and non-discrimination principles; d) animal dignity principle; e) non-cultural appropriation principle; and f) fashion designers intellectual property rights respect principle. This multidisciplinary characteristic expresses itself in different categories in the field of fashion law. In the USA, the contours of fashion law emerge in three principal groups: a) Fashion L. P. Law - involving controversies about intellectual property; b) Fashion Business Law - involving controversies about fashion contracts; and c) Fashion Public Law involving fashion labor, criminal and tax questions (ARROSI \& SOUZA, 2008). Another well-publicized classification was coordinated by Fashion Law Institute, founded by Susan Scafidi, which established the following classification: 1. Intellectual property; 2. Business and finance, including fields like investment, labor laws, and real estate market; 3. International trade and government regulations, including sustainability, privacy, and problems related to wearable technology; 4.Consumer culture and civil rights (GIRELLI, 2020).

The evolution of fashion law: The breakthroughs observed in the countries mentioned above regarding the affirmation of this new legal discipline consist, in significant part, in recognition of the legal rules involving the fashion industry in the different fields. They are already well delineated in the legal framework, as intellectual property rights, environment, labor, and others, checking and proposing adjustments to meet the fashion industry idiosyncrasies. In general, legal precedents that emerge from concrete litigations, as mentioned in designer Christian Louboutin's case, will produce quality leaps in those adjustments. In the face of the growing counterfeit phenomenon, made increasingly more accessible by new technologies, the field of intellectual property and trademark rights is, without a doubt, one of the most vulnerable in this trajectory. After approval of the Agreement on Trade-Related Aspects of Intellectual Property Rights (TRIPS) within the World Trade Organization (WTO) in 1994, most countries could count on broad specific legislation for this subject. Within the scope of this legislation precisely, litigations involving rights over creation and the protection of drawings in the fashion industry are addressed. This conduct leads to several problems. For example, the rules concerning drawings and industrial models from the TRIPS Agreement state that only original drawings created independently are the object of protection. Undoubtedly, one of fashion's features is that its artistic creation is based on a relation between creativity and legacy. In other words, the reinterpretation of past styles or existing pieces is a vital component of its creative process; this is the idea of legacy. The result is that TRIPS regulation leaves fashion drawing unprotected (SILVA, 2017). The way that each national legislation process adapted the rules referring to fashion drawing poses other problems. For example, in the USA, protection to industrial drawing does not include the notion of independence and separability, not preventing that parts of an artist's drawing be used, without authorization, on printed/stamped fabrics. In Europe, according to Abreu (2019), European Parliament established a set of rules to ensure a more uniform treatment by the national legislations, more suitable to address the industrial drawing as artwork (copyright). These would be embodied in guidelines \#98/71/CE, which addresses the legal protection of drawings and models, and \#2004/48/CE, on the intellectual property rights known as "Enforcement Rule." Fundamental to the fashion industry was the definition, in the 1998 directive, on drawing and model which should be translated into a minimum level of standardization among the Member States.

In Portugal, the new Industrial Property Code (IPC) approved in December 2018 incorporated the recommendations of the guidelines from the European Parliament. According to Abreu (2019), today, when associated with the Author and Ancillary Rights Code (ARC) local rules, it allows the provision of extensive creation, drawing, and brand protection within the Portuguese fashion industry. That even includes image rights protection to runway and photography models. However, the legislation adjustments in this specific field are not limited to creation protection. New questions are placed due to the significant increase in electronic trade, or the debate about consumption, going beyond traditional consumer protection and including themes such as responsible use and circular economy.

Fashion law and its challenges in the Brazilian context: Contrary to what happened in the US and Portugal, in Brazil, regardless of its expressive contribution to the national economy, the fashion industry has not been able to mobilize efforts to create a new legal discipline 
with a code of standards able to handle its peculiarities (MARTINS \& PEREIRA, 2020). Nonetheless, some studies regard fashion law as a new branch of law that dialogues with a cluster of other legal disciplines whose objective is grouping rules and laws to handle cases concerning the fashion industry. These peculiarities translate into legal challenges specific to this market. One example is the case of the seasonality of collections' release (FGV, 2013). We have witnessed essential controversies like the lawsuit brought by the visual artist Maria Bernadette Conte against H. Stern in 1994. The Tribunal de Justiça do Rio Grande do Sul (the Rio Grande do Sul Court) convicted this renowned jewelry brand of copying the artist's collection created around the indigenous thematic (ARROSI \& SOUZA, 2018). Another legal action that gained nationwide notoriety was the one brought by Mr. Cat, a company native to the Rio e Janeiro city, against Mr. Foot, a company from Goiás state in 1997. It was argued that the latter had copied everything from the first, resulting in Mr. Foot condemned toalter their store façade and packagings (BARIFOUSE, 2010).

Since then, there no denying that crucial decisions and advancements have been made in the sense of recognizing the existence of fashion law, including the creation of the FrenteParlamentaremDefesa da IndustriaTêxtil e de Confecção, also known as, Frente Parlamentar Mista, José Alencar, in partnership with the AssociaçãoBrasileira da indústriaTêxtil e de Confecção (ABIT), which was active from 2012 to 2106 (ABIT, 2013). Moreover, new controversies would come, allowing the development of a new market area or legal discipline, the beauty law. One example of that is the discussion in the Supremo Tribunal Federal (STF), through the AcãoDireta de Inconstitucionalidade (ADI) n. 5625, by the rapporteur, Minister Edson Fachin. In this action, the ConfederaçãoNacional dos TrabalhadoresemTurismo e Hospitalidade (CONTRATUH) contests the constitutional nature of law number 13.352, dated October 27, 2016. This law altered law number 12.592, dated January 18, 2012, the "SalãoParceiro" law, which allows a partnership agreement among professionals that work as hairdressers, barbers, beauticians, manicures, pedicures, hair removal technicians, makeup artists, or legal entities registered as beauty salons (STF, 2020). In our country, fashion law faces serious obstacles regarding its existence and autonomy. It is sometimes included in the scope of intellectual property law, other times in entertainment law, cultural law, or even innovation law. This situation must not persist given the advanced stage of the subject matter development and theme's relevance (OSMAN, 2017). Clearly, in Brazil, there have been some commendable initiatives worth mentioning. Oneexampleisthe Conselho Seccional da Ordem dos Advogados do Brasil. It envisioned the significance of the fashion industry for the Brazilian economy and the relevance of its controversies, and the importance of creating and implementing the fashion law commissions. We could also count on the acumen and sagacity of some higher education institution leaders. Upon realizing the need for a more systematized study of this Law field, some have implemented specialization programs. One example is the Faculdade Santa Marcelina, in São Paulo, which offers the specialization program entitled "Fashion law: fashion legal aspects." Another is the Centro UniversitárioMaringá (Unicesumar), which provides the specilaization "Fashion Law Direito da Moda."

However, because it is a new branch of Law and doesn't have its regulation, it has become hard to reach decisions within the scope of this segments' controversies. The legal instruments at the disposal to be used are still not clearly defined. For this reason, conflicts are solved either via judicial decision or by alternative means such as mediation, conciliation, and arbitration, utilizing other judicial order laws that, at times, do not allow an adequate solution and the consequent social pacification and legal security (FGV, 2013). Based on the exposed above, we can infer that constructing a new legal discipline or legal branch autonomy is relevant to the Law. Although the Law emerges to regulate social relations, the legal norm in our system only has the power to discipline these relations if it is written (OSMAN, 2017). Therefore, creating a new legal branch requires a coherent and autonomous set of rules adapted to a certain area of activities, that is, legislation directed towards the object of study (OSMAN, 2017).]

Concluding remarks: In conclusion, fashion law tends to be a significant aggregating factor in the fashion industry. It can provide safety to its players and be the answer to several questions whose solution is hindered due to the absence of a consolidated and autonomous set of rules. That said, fashion law has the potential to generate legal security and guarantee the solution to several legal controversies due to fashion industry internationalization that uses diverse mechanisms such as dropshipping, incoterms, chargebacks, and gentlemen's agreement whose unclear rules prevent the permanence of the Brazilian fashion industry in the international scenery. In such a context, a systematized study of fashion law becomes urgent and extremely necessary, and it is consistent with the higher education institutions' didactic and scientific autonomy. They can adapt their curricula to include the discipline fashion law into their law and design undergrad programs, following the art. 53, $\S 1^{\circ}$, III, of Law 9.394, of December 20, 1996, which establishes the guidelines and basis for national education.

\section{REFERENCES}

ABIT (2013). Associação Brasileira da Indústria Têxtil e de Confecção. Cenários, Desafios e Perspectivas. Brasília.

ABIT(2018). - Associação Brasileira da Indústria Têxtil e de Confecção. O poder a moda: Cenários, Desafios, Perspectivas e Agenda de Competividade da Indústria Têxtil e de Confecção Brasileira 2015 a 2018. São Paulo.

Abreu, L. C. (2019). Os princípios do direito da moda e sua relevância na construção e autonomia de uma nova disciplina jurídica.In L. Abreu (Ed.),Direito da Moda (pp. 12-33). Lisboa: Editora Cedis.

Arrosi, L. S.,SOUZA, G. S. de(2018).Contratos e resolução de conflitos no âmbito do direito da moda. Revista dos Tribunais, 991, 197 - 224.https://dspace.almg.gov.br/handle/11037/26400.

Bagnoli, V.(2019). As perspectivas do mercado brasileiro para o Fashion Law. In R.Soares(Ed.),Fashion Law - Direito da Moda(pp. 45-59) .São Paulo: Almedina.

Barifouse, R. (2010).O que é trade dress?Retieved from $\mathrm{http}: / /$ epocanegocios.globo.com/Revista/Common/0,EMI16046 5-16363,00-O+QUE+E+TRADE+DRESS.html

Barreto, R. (2011). Yves Saint Laurent x Louboutin. Retrieved fromhttp://fixeimagemeestilo.blogspot.com/2011/08/yves-saintlaurent-x-louboutin.html? $\mathrm{m}=0$

Bom, O. (2018). A transformação do vestir: um estudo sobre leis suntuárias, moda e modernidade. In Anais do $14^{\circ}$ Colóquio de Moda. Curitiba: PUCPR.

Brasil (1988). Lei $\mathrm{n}^{\circ}$ 9.610, de 19 de Fevereiro de 1998, que altera, atualiza e consolida a legislação sobre direitos autorais e dá outras providências. In Diário Oficial da União: República Federativa do Brasil: Poder Legislativo, Brasília, DF. Retrieved from: http://www.planalto.gov.br/ccivil_03/leis/19610.htm

Bundchen, G. (2018).Aprendizados: minha caminhada para uma vida com mais significado. (1st ed.). Rio de Janeiro: Best Seller.

Favaretto, D (2020). Direito da moda: a necessidade de uma nova postura frente a esta indústria. Retrieved from https://www. conjur.com.br/2020-ago-24/daniela-favaretto-direito-moda.

Ferreira, D. M. M. A. M.; Caminha, T. (2016). Um corpo tecnorgânico para a era da cibercultura: efeitos sobre o sexo e o gênero. Trab. Ling. Aplic,55.2, 483-502. https://doi.org/ $10.1590 / 01031813$.

Gauberti, A. (2020). Droit du luxe et de la mode en France: une vue d'ensemble en 2020.Retrieved fromhttps://village-justice.com/ articles/droit-luxe-mode-france-une-vue-ensemble-2020 ,36350.html

Girelle, C. S.(2020). Susan Scafidi: uma breve biografia. InC. Serraggio, G. e T. da Silva José (Eds.).Fashion Law: o amparo jurídico para a indústria da moda. Porto Alegre: ABA. 
Guimarães, F. Entenda o que é a alta-costura na moda. Retrieved from https://revistamarieclaire.globo.com/amp-stories/entendao-que-e-a-alta-costura-na-moda/index.html.

Heemstede, F.T. V.,Orsovay, N.Y(2018). A possibilidade de autorregulação do mercado da moda do Brasil. In Mônica Rosina, e Maria Fernanda Cury (Eds.) Fashion Law: direito e moda no Brasil(pp. 171-184). São Paulo: Thomas Reuters.

Ibaixe.JR. J.,Sabóia (2014).V.Caso Christian Louboutin contra Yves Saint Laurent: Nascimento do Direito da Moda.Retrieved from https://www.migalhas.com.br/depeso/203478/caso-christianlouboutin-contra-yves-saint-laurent-nascimento-do-direito-damoda.

Jimenez, G. C. (2013). Fashion Law - Overview of a New Legal Discipline. In G.C. Jimenez, B.Kolsun (Eds.) Fashion Law: A guide for Designers, Fashion Executives and Attorneys. New York, USA: Ed. Fairchild Books.

Kaddouri, S. K. (2018). "Fashion Law": La France, Patrie Du Luxe, N'A Toujours Pas Son Droit De La Mode.Retrieved from: https://www.forbes.fr/luxe/fashion-law-la-france-patrie-du-luxena-toujours-pas-son-droit-de-la-mode/.

Le Monde Du Droit. Fashion Law : L'Europe s'empare du droit de la mode. Retrieved from: https://www.lemondedudroit.fr/decryptages/60272-fashion-laweurope-empare-droit-mode.html

Lira, C. (2015). As primeiras linhas do direito da moda no Brasil.Retrieved from https://jus.com.br/artigos/41999/asprimeiras-linhas-do-direito-da-moda-no-brasil.

Martins, S. L. A.; Pereira, C. L. A (2020). Mas o que é este tal de fashion law? Qual a sua importância para os negócios da moda? InN. C. P.FinottiTessituras da moda: diálogos entre o vestir, modos e comportamentos (pp. 55-70). Goiânia: Editora Scotti.

Miranda, A. P. de. (2008).Consumo de moda: a relação pessoaobjeto. São Paulo: Estação das Letras e Cores.

Neto, C. de B. C (2016). Formação do direito tributário como disciplina jurídica: recortes e exclusões. InRevista do Programa de Pós-Graduação em Direito da UFC, 36.1. Ritrievedfrom:http://periodicos.ufc.br/nomos/article/view/1287.
Oliveira, F. Autonomia, denominação e natureza jurídica do Direito do Trabalho. Ritrieved from: https://www.direitonet.com.br/ artigos/exibir/1679/Autonomia-denominacao-e-naturezajuridica-do-Direito-do-Trabalho\#: : :text=Alfredo $\% 20$ Rocco\%20\%5B1\%5D\%20prop\%C3\%B5e\%20tr\%C3\%AAs,do $\% 20$ Trabalho\%20preenche $\% 20$ tais $\% 20$ requisitos.

Osman, B. H. de S. (2017). Fashion Law: desconstrução do direito da moda no Brasil. Retrieved from: http://tede.mackenzie.br/ jspui/handle/tede/3408.

Pitta, D. (2011). Sobre as Leis Suntuárias na História. Retrieved from: https://fashionbubbles.com/historia-da-moda/sobre-as-leissuntuarias-na-historia/.

Pomin, A. V. C. (2017). Propriedade Intelectual na moda.Volume 1. Maringá-Pr.: UniCesumar.

Prado, L. A. do (2019). Indústria do vestuário e moda no Brasil do século XIX a 1960: da cópia e adaptação a autonomização subordinada. Retrieved from: https://teses.usp.br/teses/ disponiveis/8/8137/tde-16102019-145105/pt-br.php.

Prochnik, V. Firma, Indústria e Mercados. In:Hasenclever, L., Kupfer, D. Organização Industrial.São Paulo: Ed. Campus.

Quaresma, D. M. M. etc et al (2015). Fashion law e o plágio na moda. Retrieved from http://www.coloquiomoda.com.br/ anais/Coloquio $\% 20 \mathrm{de} \% 20$ Moda $\% 20-\% 202015 /$ COMUN ICACAO-ORAL/CO-EIXO3-CULTURA/CO-3-FASHIONLAW-E-O-PLAGIO-NA-MODA.pdfGAUBERTI

Rech, S. R.Estrutura da Cadeia Produtiva da Moda. Moda Palavra e Periódico, 1, 7-20. Retrievedfrom: http://www.revistas.udesc.br/ index.php/modapalavra/article/viewFile/7565/5068 2020.

Rocco, A. (2003). Princípios de Direito Comercial. Campinas: LZN Editora.

Scafidi, $S$ (2015.). Introduction: Fashion Law Triumphant Designing Success in a New Legal Field. In Scafidi, S. et all Fashion Law: Leading Lawyers on Developing Client Brands in a Changing Market and Monitoring Key Legal Developments. Eagan, USA: Thomson Reuters.

STF - Supremo Tribunal Federal (2020). Conheça os destaques das 27 sessões de julgamento do Plenário do STF convocadas até dezembro.Retrieved from: http://portal.stf.jus.br/noticias/ verNoticiaDetalhe.asp?idConteudo=451941\&ori $=1$ 